ISSN 1678-3921

Journal homepage: www.embrapa.br/pab

For manuscript submission and journal contents, access: www.scielo.br/pab

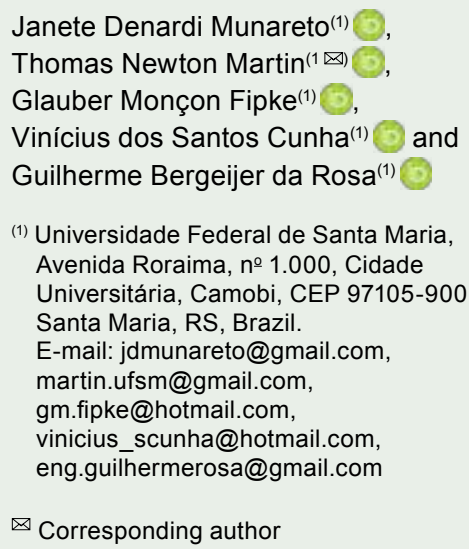

How to cite MUNARETO, J.D.; MARTIN, T.N.; FIPKE, G.M.; CUNHA, V. dos S.; ROSA, G.B. da. Nitrogen management alternatives using Azospirillum brasilense in wheat. Pesquisa Agropecuária Brasileira, v.54, e00276, 2019. DOI: https://doi.org/10.1590/S1678-3921. pab2019.v54.00276.

\section{Nitrogen management alternatives using Azospirillum brasilense in wheat}

\begin{abstract}
The objective of this work was to evaluate nitrogen management alternatives using Azospirillum brasilense inoculation in wheat (Triticum aestivum) by seed and foliar applications. Treatments consisted of the inoculation or not of $A$. brasilense, via seed and leaves, associated with topdressing with 0,70 , and $140 \mathrm{~kg} \mathrm{ha}^{-1}$ nitrogen. Three wheat cultivars were tested: BRS Parrudo, TBIO Quartzo, and TBIO Sinuelo. The experimental design was a randomized complete block, with three replicates. The following traits were evaluated: number of emerged plants, tillers, spikelets per ear, grains per ear, and grains per spikelet; 1,000-grain mass; hectoliter mass; and grain yield. The foliar management of $A$. brasilense showed a better association with the TBIO Sinuelo cultivar. The foliar application of $A$. brasilense, whether alone or combined with seed treatment, increases the grain yield and yield components of the evaluated cultivars.
\end{abstract}

Index terms: Triticum aestivum, diazotrophic bacteria, foliar spraying, grain quality.

\section{Alternativas do manejo nitrogenado com uso de Azospirillum brasilense em trigo}

\begin{abstract}
Resumo - O objetivo deste trabalho foi avaliar alternativas de manejo do nitrogênio em trigo (Triticum aestivum), com uso da inoculação de Azospirillum brasilense nas sementes e nas folhas. Os tratamentos consistiram da inoculação ou não de $A$. brasiliense, via sementes ou folhas, associada a fertilizações de cobertura com 0,70 e $140 \mathrm{~kg} \mathrm{ha}^{-1}$ de nitrogênio. Três cultivares de trigo foram testadas: BRS Parrudo, TBIO Quartzo e TBIO Sinuelo. O delineamento experimental utilizado foi em blocos ao acaso, com três repetições. Avaliaram-se as seguintes características: número de plantas emergidas, de perfilhos, de espiguetas por espigas, de grãos por espiga e de grãos por espigueta; massa de mil grãos; massa de hectolitro; e produtividade de grãos. O manejo foliar de $A$. brasilense apresentou melhor associação com a cultivar TBIO Sinuelo. A aplicação de $A$. brasilense via foliar, realizada individualmente ou associada ao tratamento de sementes, aumenta a produtividade de grãos e os componentes de produtividade das cultivares avaliadas.
\end{abstract}

Termos para indexação: Triticum aestivum, bactéria diazotrófica, pulverização foliar, qualidade do grão.

\section{Introduction}

Climatic adversity, especially excessive rainfall and frost during the anthesis of wheat (Triticum aestivum L.), compromises grain yield and quality (Carvalho \& Beleia, 2015). 
Nitrogen influences physiological processes such as plant photosynthesis, respiration, development, and growth, as well as cell differentiation. In addition, it is a constituent of all amino acids, proteins, nucleic acids, amides, and coenzymes. Wheat absorbs approximately $120 \mathrm{~kg} \mathrm{ha}^{-1}$ nitrogen until the anthesis period, and the efficiency of nitrogen use by plants varies between 12 $21 \mathrm{~kg}$ per kilogram of added nitrogen (Wiethölter, 2011).

The management of nitrogen fertilization is complex due to the large number of possible reactions and losses of this nutrient (Teixeira Filho et al., 2010). To overcome this complexity, alternatives are being investigated, such as the use of diazotrophic bacteria (Bergamaschi et al., 2007) to substitute or to supplement nitrogen fertilization (Hungria et al., 2010). Besides crop productivity, these bacteria can also improve soil fertility and structure, while reducing negative impacts of chemical fertilizers on the environment. Azospirillum brasilense is one bacterium commonly used in association with corn (Zea mays L.) and wheat crops (Piccinin et al., 2013). It produces phytohormones, increases root growth, solubilizes phosphates, improves photosynthetic parameters and stomatal conductance, induces systemic resistance to diseases, and mitigates saline stress (Bashan \& deBashan, 2010). Moreover, it can provide 12 to $79 \%$ of a plant's nitrogen requirements, with observed increases of 27 and $31 \%$ in the grain yield of corn and wheat, respectively (Hungria et al., 2010).

Most research use $A$. brasilense for seed inoculation, via solid (peat) or liquid formulations. However, foliar application can also be used, providing different plant responses due to the absorption by the leaf tissue, where the metabolism of amino acids, vitamins, hormones, and coenzymes occurs (Bashan \& de-Bashan, 2010). Foliar application also allows avoiding incompatibility between the bacterium and both fungicides and insecticides, which could impair bacterial survival and plant growth (Cornacini \& Alves, 2014).

Several studies have shown the efficiency of the association of bacteria with nitrogen doses (Silva et al., 2009; Lana et al., 2012). However, grain yield efficiency is either low or not observed in these studies (Mehnaz et al., 2010). Complex interactions between plants, bacteria, and environment are responsible for the variability in the obtained results, since these interactions can alter nitrogen fixation capacity and phytohormone production (Sala et al., 2007).
The objective of this work was to evaluate nitrogen management alternatives using Azospirillum brasilense inoculation in wheat by seed and foliar applications.

\section{Materials and Methods}

The experiment was conducted between 2014 and 2015, in an experimental area of Universidade Federal de Santa Maria, located in the municipality of Santa Maria, in the state of Rio Grande do Sul, Brazil (29 $43^{\prime} 03^{\prime \prime} \mathrm{S}, 53^{\circ} 44^{\prime} 00^{\prime \prime} \mathrm{W}$, at $116 \mathrm{~m}$ altitude). The climate of the region is Cfa, humid subtropical, with hot summers and without a defined dry season, according to Köppen's classification (Heldwein et al., 2009). The mean air temperature is $13.8^{\circ} \mathrm{C}$ in June and July and $24.7^{\circ} \mathrm{C}$ in January, while the annual precipitation is $1,712.4 \mathrm{~mm}$ (Heldwein et al., 2009). The soil was classified as a sandy Argissolo Vermelho distrófico (Santos et al., 2013), i.e., a Rhodic Paleudalf.

The experiment used a randomized complete block design, in a $3 \times 4 \times 3$ factorial arrangement, with three replicates. The evaluated factors were: three wheat cultivars - BRS Parrudo, TBIO Quartzo, and TBIO Sinuelo; four inoculation forms - seed application, foliar application, foliar + seed application, and control; and three doses of nitrogen topdressing fertilization 0,70 , and $140 \mathrm{~kg} \mathrm{ha}^{-1}$ nitrogen. The area was desiccated 20 days before the installation of the experiments with $3.5 \mathrm{~L} \mathrm{ha}^{-1}$ glyphosate. The seeds were treated with the insecticide thiamethoxam (Cruiser 350 FS, Sygenta Brasil, São Paulo, SP, Brazil) and the fungicide difenoconazole (Spectro, Sygenta Brasil, São Paulo, SP, Brazil), at the doses of 200 and $150 \mathrm{~mL}$ per 100 $\mathrm{kg}^{-1}$ seeds, respectively. Moments before sowing, $2.0 \times 10^{8} \mathrm{CFU} \mathrm{mL} \mathrm{m}^{-1}$ of the bacterium were applied to the seeds, which were shaken in polyethylene bags, in order to homogenize the inoculant containing the AbV5 and AbV6 A. brasilense strains, obtained from the commercial product AzoTotal (Total Biotecnologia Indústria e Comércio Ltda., Curitiba, PR, Brazil).

The wheat crop was sown on 6/11/2014 and 6/3/2015. Each experimental unit consisted of $3.87-\mathrm{m}$ rows $\mathrm{x}$ 2.00 - $\mathrm{m}$ width, with $0.2 \mathrm{~m}$ between rows, with a sowing density of 300 to 330 viable seeds per square meter. The six central rows of each experimental unit were taken as useful plots. For base fertilization, $450 \mathrm{~kg} \mathrm{ha}^{-1}$ of the $\mathrm{N}-\mathrm{P}_{2} \mathrm{O}_{5}-\mathrm{K}_{2} \mathrm{O}$ fertilizer (00-23-30) were used, according to the soil analysis. Phosphorus and potassium sources 
were triple superphosphate $\left(42 \% \mathrm{P}_{2} \mathrm{O}_{5}\right)$ and potassium chloride $\left(58 \% \mathrm{~K}_{2} \mathrm{O}\right)$. Nitrogen topdressing fertilization for the treatments with 70 and $140 \mathrm{~kg} \mathrm{ha}^{-1}$ was divided into two applications: the first, at the start of tillering, on 7/22/2014 and 7/7/2015; and the second, at the end of tillering, on $8 / 29 / 2014$ and $6 / 8 / 2015$, using urea as a source ( $45 \%$ nitrogen).

At the beginning and at the end of tillering, 500 $\mathrm{mL}$ ha $^{-1}$ A. brasilense (AzoTotal, Total Biotecnologia Indústria e Comércio Ltda., Curitiba, PR, Brazil) were applied to the leaves in the late afternoon. For foliar application, an electric shoulder sprayer was used, with an empty cone jet tip and an output of $180 \mathrm{~L} \mathrm{ha}^{-1}$. The remainder of the cultivation practices were carried out according to the technical recommendations for the wheat crop (Reunião..., 2017).

The total number of emerged plants per square meter and of tillers per plant was measured during the experiment, in a 1.0-m line, in each experimental unit. Harvest was carried out on 10/2/2014 and 8/24/2015. Afterwards, the following yield components were evaluated in ten plants from each plot: number of spikelets per ear, number of grains per ear, and number of grains per spikelet. Grain yield $\left(\mathrm{kg} \mathrm{ha}^{-1}\right)$ was obtained by harvesting the usable area of each plot, with values adjusted to $13 \%$ moisture. Hectoliter mass $\left(\mathrm{kg} \mathrm{h}^{-1}\right)$ was determined on a hectoliter scale. The 1,000-grain mass (g) was measured by direct counting of the grains, and mass was corrected to $13 \%$ moisture content. The data were subjected to the analysis of variance, and means were compared by Scott-Knott's test, at 5\% probability, using the Sisvar software (Ferreira, 2011).

\section{Results and Discussion}

In 2014, both inoculation and cultivars had significant effects on 1,000-grain mass, with a double interaction between these factors for hectoliter mass and number of tillers. There was a triple interaction between inoculation, cultivar, and nitrogen dose for number of spikelets per ear, number of grains per ear, number of grains per spikelet, and grain yield. In 2015, the studied cultivars affected 1,000-grain mass, whereas inoculation and nitrogen dose influenced the number of grains per ear. There was a double interaction between cultivars and nitrogen doses for hectoliter mass, and a triple interaction between cultivars, inoculation, and nitrogen doses for number of spikelets per ear and grain yield.

The number of emerged plants and the number of tillers were analyzed separately because the latter did not receive all nitrogen doses and inoculation was performed only in seeds. In both study years, there was no significant effect of nitrogen application or of inoculation with $A$. brasilense on the number of emerged plants. As the soil environment is competitive and complex, both nitrogen and bacteria may have been affected by climatic variations during plant establishment. At the beginning of colonization, the bacterium is vulnerable to temperature and humidity oscillations (Dobbelaere et al., 2003). In addition, the competition with other soil bacteria possibly left insufficient time for the inoculated ones to establish and promote morphophysiological changes in roots up to the point of influencing the number of emerged plants (Bashan \& de-Bashan, 2010).

The number of tillers was affected by the inoculation of $A$. brasilense in the BRS Parrudo and TBIO Sinuelo cultivars; with the control, 1.5 and 1.6 tiller per plants were obtained, respectively, and, with seed inoculation, 2.5 tillers per plant. It should be noted that differences in the number of tillers might be due to the inherent traits of each cultivar, whereas the emission of tillers depends on environmental, nutritional, and genetic conditions. The cultivar influences the microbial community present in the roots by specific signaling between root and bacterium (Monteiro et al., 2012). Furthermore, nodulation alters the morphology of roots and can improve the absorption of nutrients, mainly nitrogen (Bashan \& de-Bashan, 2010).

In 2014, the first experimental year, the inoculation method did not influence the number of spikelets per ear, regardless of cultivar and nitrogen dose, corroborating the findings of Teixeira Filho et al. (2010). This may occur in conditions where the soil provides a favorable environment for plants, leaving no possibility for responses due to the implemented management practices.

The number of spikelets per ear and the number of grains per ear in 2015 (Tables 1 and 2) responded to the associated inoculation of leaves and seeds, without the addition of nitrogen. For the BRS Parrudo and TBIO Quartzo cultivars, the number of spikelets per ear increased 7 and $6 \%$, respectively. These results are indicative that the combined inoculation has great 
potential in providing nitrogen continuously until the reproductive phase of the plant. The TBIO Sinuelo cultivar responded to foliar inoculation of $A$. brasilense associated with $140 \mathrm{~kg} \mathrm{ha}^{-1}$ nitrogen (Table 1). This kind of response can vary depending on the used nitrogen dose and the interaction between plantbacteria-environment (Sala et al., 2007). However, Galindo et al. (2017) tested the foliar application of $A$. brasilense with different $\mathrm{N}$ doses, in irrigated wheat, and did not observe any influence of foliar inoculation on yield, number of spikelets per ear, grains per spike, or grains per spikelet. In this case, environmental and management conditions may have inhibited the manifestation of the effect of the bacteria.

The number of grains per ear and grains per spikelet showed a pattern in response to the forms of inoculation,

Table 1. Number of spikelets per spike of wheat (Triticum aestivum) cultivars subjected to different forms of inoculation with Azospirillum brasilense and nitrogen doses in the 2014 and 2015 crop years ${ }^{(1)}$.

\begin{tabular}{|c|c|c|c|c|c|}
\hline \multirow{2}{*}{$\begin{array}{l}\mathrm{N} \text { dose } \\
\left(\mathrm{kg} \mathrm{ha}^{-1}\right)\end{array}$} & \multirow[t]{2}{*}{ Cultivar } & \multicolumn{4}{|c|}{ Inoculation form } \\
\hline & & Control & Foliar $(\mathrm{F})$ & Seed (S) & $\mathrm{F}+\mathrm{S}$ \\
\hline & \multicolumn{5}{|c|}{2014} \\
\hline & BRS Parrudo & $\alpha 17.2 \mathrm{aA} *$ & $\alpha 15.8 \mathrm{bA}$ & $\alpha 17.8 \mathrm{aA}$ & $\alpha 17.6 \mathrm{aA}$ \\
\hline \multirow[t]{3}{*}{0} & TBIO Sinuelo & $\beta 14.5 \mathrm{bA}$ & $\alpha 15.7 \mathrm{bA}$ & $\alpha 18.0 \mathrm{aA}$ & $\alpha 16.5 \mathrm{aA}$ \\
\hline & TBIO Quartzo & $\alpha 16.4 \mathrm{aA}$ & $\alpha 18.2 \mathrm{aA}$ & $\alpha 17.4 \mathrm{aA}$ & $\alpha 17.6 \mathrm{aA}$ \\
\hline & BRS Parrudo & $\alpha 16.4 \mathrm{aA}$ & $\alpha 18.2 \mathrm{aA}$ & $\alpha 18.0 \mathrm{aA}$ & $\alpha 18.3 \mathrm{aA}$ \\
\hline \multirow[t]{3}{*}{70} & TBIO Sinuelo & $\alpha 18.0 \mathrm{aA}$ & $\alpha 17.7 \mathrm{aA}$ & $\alpha 16.5 \mathrm{aA}$ & $\alpha 18.0 \mathrm{aA}$ \\
\hline & TBIO Quartzo & $\alpha 17.5 \mathrm{aA}$ & $\alpha 15.8 \mathrm{aA}$ & $\alpha 18.0 \mathrm{aA}$ & $\alpha 18.3 \mathrm{aA}$ \\
\hline & BRS Parrudo & $\alpha 17.5 \mathrm{aA}$ & $\alpha 17.7 \mathrm{aA}$ & $\alpha 17.4 \mathrm{aA}$ & $\beta 15.2 \mathrm{bB}$ \\
\hline \multirow[t]{2}{*}{140} & TBIO Sinuelo & $\alpha 17.6 \mathrm{aA}$ & $\alpha 17.0 \mathrm{aA}$ & $\alpha 17.5 \mathrm{aA}$ & $\alpha 17.8 \mathrm{aA}$ \\
\hline & TBIO Quartzo & $\alpha 17.2 \mathrm{aA}$ & $\alpha 17.7 \mathrm{aA}$ & $\alpha 17.8 \mathrm{aA}$ & $\alpha 15.2 \mathrm{bB}$ \\
\hline \multirow[t]{3}{*}{ CV (\%) } & & \multicolumn{4}{|c|}{3.7} \\
\hline & \multicolumn{5}{|c|}{2015} \\
\hline & BRS Parrudo & $\mathrm{Y} 15.4 \mathrm{aB}$ & $\mathrm{Y} 15.7 \mathrm{aB}$ & $\mathrm{Y} 14.4 \mathrm{aC}$ & $\beta 16.6 \mathrm{aA}$ \\
\hline \multirow[t]{3}{*}{0} & TBIO Sinuelo & $\beta 15.4 \mathrm{aA}$ & $\beta 15.4 \mathrm{aA}$ & $\mathrm{Y} 14.4 \mathrm{aB}$ & $\beta 14.3 \mathrm{cB}$ \\
\hline & TBIO Quartzo & $\mathrm{Y} 14.4 \mathrm{aB}$ & Y14.6bB & $\mathrm{Y} 14.7 \mathrm{aB}$ & $\alpha 15.3 \mathrm{bA}$ \\
\hline & BRS Parrudo & $\beta 16.5 \mathrm{aA}$ & $\beta 16.5 \mathrm{aA}$ & $\beta 16.0 \mathrm{aA}$ & $\beta 16.5 \mathrm{aA}$ \\
\hline \multirow[t]{3}{*}{70} & TBIO Sinuelo & $\beta 15.3 \mathrm{bA}$ & $\beta 15.5 \mathrm{bA}$ & $\beta 15.2 \mathrm{bA}$ & $\beta 14.7 \mathrm{bB}$ \\
\hline & TBIO Quartzo & $\beta 16.3 \mathrm{aA}$ & $\beta 15.5 \mathrm{bB}$ & $\beta 16.2 \mathrm{aA}$ & $\alpha 16.3 \mathrm{aA}$ \\
\hline & BRS Parrudo & $\alpha 18.5 \mathrm{aA}$ & $\alpha 18.4 \mathrm{aA}$ & $\alpha 17.5 \mathrm{aB}$ & $\alpha 17.3 \mathrm{aB}$ \\
\hline \multirow[t]{2}{*}{140} & TBIO Sinuelo & $\alpha 16.7 \mathrm{bB}$ & $\alpha 17.3 \mathrm{bA}$ & $\alpha 16.3 b C$ & $\alpha 16.0 \mathrm{bC}$ \\
\hline & TBIO Quartzo & $\alpha 17.2 \mathrm{bA}$ & $\alpha 17.4 \mathrm{bA}$ & $\alpha 15.6 \mathrm{cC}$ & $\alpha 16.4 \mathrm{bB}$ \\
\hline $\mathrm{CV}($ & & \\
\hline
\end{tabular}

(1) Means followed by equal letters, lowercase in the columns within nitrogen doses and uppercase in the rows, do not differ by Scott-Knott's test, at $5 \%$ probability. Greek letters in front of the averages compare nitrogen doses within inoculation treatments and years. in 2014 (Table 2). Foliar inoculation with A. brasilense in the TBIO Sinuelo cultivar was the most efficient for number of grains per ear, regardless of nitrogen fertilization. In the BRS Parrudo and TBIO Quartzo cultivars, seed inoculation, whether associated or not with nitrogen doses, and seed inoculation plus nitrogen doses also helped to improve this trait. Moreover, 70 $\mathrm{kg} \mathrm{ha}^{-1}$ nitrogen plus foliar inoculation was sufficient to increase the number of grains per ear in the TBIO Sinuelo cultivar.

In 2015, foliar and seed inoculation increased the number of grains per ear in $19.71 \%$, compared with the treatment without inoculation. With the combined inoculation, the average number of grains per ear was 34 , while, with seed inoculation and the control, it was of 30 and 28 grains per ear, respectively, showing a

Table 2. Number of grains per ear and per spikelet of wheat (Triticum aestivum) cultivars subjected to different forms of inoculation with Azospirillum brasilense and nitrogen doses in the 2014 and 2015 crop years $^{(1)}$.

\begin{tabular}{|c|c|c|c|c|c|}
\hline \multirow{2}{*}{$\begin{array}{l}\text { N dose } \\
\left(\mathrm{kg} \mathrm{ha}^{-1}\right)\end{array}$} & \multirow{2}{*}{ Cultivar } & \multicolumn{4}{|c|}{ Inoculation form } \\
\hline & & Control & Foliar $(\mathrm{F})$ & Seed $(S)$ & $\mathrm{F}+\mathrm{S}$ \\
\hline & \multicolumn{5}{|c|}{ Number of grains per ear in 2014} \\
\hline & BRS Parrudo & $\alpha 32.0 \mathrm{aB} *$ & $\beta 23.0 \mathrm{bD}$ & $\beta 35.0 \mathrm{bA}$ & $\mathrm{Y} 26.3 \mathrm{aC}$ \\
\hline \multirow[t]{3}{*}{0} & TBIO Sinuelo & $\beta 23.0 \mathrm{cB}$ & $\beta 25.5 \mathrm{aA}$ & $\mathrm{Y} 23.4 \mathrm{cB}$ & $\mathrm{Y} 23.4 \mathrm{bB}$ \\
\hline & TBIO Quartzo & $\beta 27.0 \mathrm{bB}$ & $\beta 21.1 \mathrm{bC}$ & $\alpha 37.5 \mathrm{aA}$ & $\mathrm{Y} 26.3 \mathrm{aC}$ \\
\hline & BRS Parrudo & $\beta 27.0 \mathrm{bC}$ & $\beta 21.1 \mathrm{bD}$ & $\beta 33.8 \mathrm{aA}$ & $\beta 29.1 \mathrm{bB}$ \\
\hline \multirow[t]{3}{*}{70} & TBIO Sinuelo & $\alpha 31.4 \mathrm{aB}$ & $\alpha 35.3 \mathrm{aA}$ & $\beta 32.6 \mathrm{aB}$ & $\alpha 33.3 \mathrm{aB}$ \\
\hline & TBIO Quartzo & $\beta 26.0 \mathrm{bC}$ & $\beta 23.0 \mathrm{bD}$ & $\beta 33.8 \mathrm{aA}$ & $\beta 29.1 \mathrm{bB}$ \\
\hline & BRS Parrudo & $\beta 26.0 \mathrm{bD}$ & $\alpha 28.0 \mathrm{bC}$ & $\alpha 37.5 \mathrm{aA}$ & $\alpha 34.3 \mathrm{aB}$ \\
\hline \multirow[t]{2}{*}{140} & TBIO Sinuelo & $\alpha 32.4 \mathrm{aB}$ & $\alpha 36.6 \mathrm{aA}$ & $\alpha 38.2 \mathrm{aA}$ & $\beta 29.5 \mathrm{bC}$ \\
\hline & TBIO Quartzo & $\alpha 32.0 \mathrm{aB}$ & $\alpha 28.0 \mathrm{bC}$ & $\beta 34.8 \mathrm{aA}$ & $\alpha 34.3 \mathrm{aA}$ \\
\hline \multirow[t]{3}{*}{$\mathrm{CV}(\%)$} & & \multicolumn{4}{|c|}{3.7} \\
\hline & \multicolumn{5}{|c|}{ Number of grains per spikelet in 2015} \\
\hline & BRS Parrudo & $\alpha 1.8 \mathrm{aA}$ & $\alpha 1.4 \mathrm{aB}$ & $\beta 2.0 \mathrm{aA}$ & $\beta 1.5 \mathrm{aB}$ \\
\hline \multirow[t]{3}{*}{0} & TBIO Sinuelo & $\alpha 1.6 \mathrm{aA}$ & $\beta 1.6 \mathrm{aA}$ & $\beta 1.3 \mathrm{bB}$ & $\beta 1.4 \mathrm{aB}$ \\
\hline & TBIO Quartzo & $\beta 1.6 \mathrm{aB}$ & $\beta 1.1 \mathrm{bC}$ & $\alpha 2.1 \mathrm{aA}$ & $\beta 1.5 \mathrm{aB}$ \\
\hline & BRS Parrudo & $\beta 1.6 \mathrm{aB}$ & $\beta 1.1 \mathrm{cC}$ & $\beta 1.8 \mathrm{aA}$ & $\beta 1.6 \mathrm{bB}$ \\
\hline \multirow[t]{3}{*}{70} & TBIO Sinuelo & $\alpha 1.7 \mathrm{aA}$ & $\alpha 2.0 \mathrm{aA}$ & $\alpha 1.9 \mathrm{aA}$ & $\alpha 1.8 \mathrm{aA}$ \\
\hline & TBIO Quartzo & $\beta 1.5 \mathrm{aB}$ & $\alpha 1.4 \mathrm{bB}$ & $\beta 1.9 \mathrm{aA}$ & $\beta 1.5 \mathrm{bB}$ \\
\hline & BRS Parrudo & $\beta 1.5 \mathrm{bB}$ & $\alpha 1.6 \mathrm{aB}$ & $\alpha 2.1 \mathrm{aA}$ & $\alpha 2.2 \mathrm{aA}$ \\
\hline \multirow[t]{2}{*}{140} & TBIO Sinuelo & $\alpha 1.8 \mathrm{aB}$ & $\alpha 2.1 \mathrm{aA}$ & $\alpha 2.1 \mathrm{aA}$ & $\alpha 1.6 \mathrm{bB}$ \\
\hline & TBIO Quartzo & $\alpha 1.8 \mathrm{aB}$ & $\alpha 1.6 \mathrm{bC}$ & $\beta 2.0 \mathrm{aB}$ & $\alpha 2.2 \mathrm{aA}$ \\
\hline $\mathrm{CV}$ & & \multicolumn{4}{|c|}{8.25} \\
\hline
\end{tabular}


statistically significant superiority of the combined treatment.

In both years, the increased number of grains per ear occurred due to the efficiency of the tested inoculant, whether applied to the seed or leaf. Nitrogen doses associated with inoculation also positively affected this variable. Piccinin et al. (2013), working with $A$. brasilense and nitrogen doses in wheat, observed an increased number of spikelets per ear and of grains per ear. According to the authors, the inoculation with $A$. brasilense must be associated with nitrogen fertilization to favor agronomic characteristics in the wheat crop, because it alone cannot supply the amount of nitrogen required by the plant.

For hectoliter mass (Table 3), the inoculation with A. brasilense and nitrogen fertilization had no effect in neitheryear, which is consistent with the results reported by Sangoi et al. (2007). The TBIO Parrudo cultivar, in 2014, and TBIO Sinuelo, in 2015, had the highest hectoliter mass values. According to Franceschi et al. (2009), variations in hectoliter mass are attributed to genotype and environment interactions. In the present study, the low hectoliter mass in 2015 may be due to the high temperatures during the vegetative and the grain-filling phases. Another factor that might have influenced this trait, along with experimental years, was the high rainfall indices and the strong winds before the physiological maturation of wheat, causing plant lodging; the bedded plants left the spikes near the ground, where humidity activates the enzymatic processes of the seed. The enzymes, when activated, promote changes in starch and proteins, initiating the germination process in the spike (Franceschi et al., 2009), reducing grain quality. Therefore, for this trait, genetic and environmental factors were expressed more intensely than the management with $A$. brasilense.
Azospirillum brasilense, whether inoculated in the seed or in association with foliar applications, allowed for an improved use of nutrients and for their efficient translocation to the grains, increasing the 1,000-grain mass in $2 \mathrm{~g}$, on average, compared with the other inoculation treatments (Table 4). Cornacini \& Alves (2014) also observed increases in the 1,000-grain mass with foliar applications in sorghum [Sorghum bicolor (L.) Moench]. In the present study, the TBIO Quartzo cultivar produced grains with greater mass than the other ones. It should be pointed out that increases in grain mass are commonly associated with greater nitrogen availability, provided by the bacterium during the flowering phase and the beginning of grain filling (Sangoi et al., 2007). However, grains with higher mass do not necessarily guarantee higher productivity per area to the wheat crop.

Only cultivar and nitrogen doses affected grain yield in 2014 (Table 5). In 2015, foliar inoculation allowed an increase of $270 \mathrm{~kg} \mathrm{ha}^{-1}$ with half of the nitrogen dose of $70 \mathrm{~kg} \mathrm{ha}^{-1}$, compared with the control. In this year, the productivity with $70 \mathrm{~kg} \mathrm{ha}^{-1}$ nitrogen and inoculation was similar to that with $140 \mathrm{~kg} \mathrm{ha}^{-1}$ nitrogen without inoculation. This result reinforces the hypothesis that the inoculation of $A$. brasilense plus $70 \mathrm{~kg} \mathrm{ha}^{-1}$ nitrogen can reduce the fertilization of this nutrient in the wheat crop by up to $50 \%$ (Piccinin et al., 2013).

The Sinuelo cultivar showed a more consistent response to inoculation along the two study years (Table 5). In the first year, productivity increased from $1,440 \mathrm{~kg}$ with $70 \mathrm{~kg} \mathrm{ha}^{-1}$ nitrogen to $2,627 \mathrm{~kg} \mathrm{ha}^{-1}$ with inoculation plus the same nitrogen dose, showing an increase of approximately $82.5 \%$ in relation to the treatment without $A$. brasilense. In the second year, foliar inoculation plus $70 \mathrm{~kg}^{-1}$ nitrogen increased the cultivar's grain yield from 2,872 to $3,242 \mathrm{~kg} \mathrm{ha}^{-1}$.

Table 3. Hectoliter mass $\left(\mathrm{kg} \mathrm{h}^{-1}\right)$ of wheat (Triticum aestivum) cultivars subjected to different forms of inoculation with Azospirillum brasilense and nitrogen doses in the 2014 and 2015 crop years $^{(1)}$.

\begin{tabular}{|c|c|c|c|c|c|c|c|}
\hline \multirow[t]{2}{*}{ Cultivar } & \multicolumn{4}{|c|}{ Inoculation form in 2014} & \multicolumn{3}{|c|}{ Nitrogen dose $\left(\mathrm{kg} \mathrm{ha}^{-1}\right)$ in 2015} \\
\hline & Control & Foliar (F) & Seed $(\mathrm{S})$ & $\mathrm{F}+\mathrm{S}$ & 0 & 70 & 140 \\
\hline BRS Parrudo & $78.6 \mathrm{aA} *$ & $79.2 \mathrm{aA}$ & $76.8 \mathrm{aB}$ & $78.5 \mathrm{aA}$ & $70.6 \mathrm{aA}$ & $70.4 \mathrm{aA}$ & $70.0 \mathrm{bA}$ \\
\hline TBIO Sinuelo & $75.8 \mathrm{bA}$ & $76.1 \mathrm{bA}$ & $77.0 \mathrm{aA}$ & $76.9 \mathrm{bA}$ & $72.0 \mathrm{aA}$ & $70.0 \mathrm{aA}$ & $71.0 \mathrm{aA}$ \\
\hline TBIO Quartzo & $76.4 \mathrm{bA}$ & $75.4 \mathrm{bA}$ & $76.5 \mathrm{aA}$ & $76.5 \mathrm{bA}$ & $70.4 \mathrm{aA}$ & $70.0 \mathrm{aA}$ & $70.0 \mathrm{bA}$ \\
\hline CV (\%) & \multicolumn{4}{|c|}{1.9} & \multicolumn{3}{|c|}{2.84} \\
\hline
\end{tabular}

(1)Means followed by equal letters, lowercase in the columns within nitrogen doses and uppercase in the rows, do not differ by Scott-Knott's test, at 5\% probability. 
Hungria et al. (2010) reported that in 273 wheat trials with $A$. brasilense inoculation, in Argentina, average productivity was $256 \mathrm{~kg} \mathrm{ha}^{-1}$, increasing in $76 \%$ of the cases. These results are attributed to the efficiency of the bacterium in providing nitrogen to the plants, with better responses when soil nitrogen supply is limited (Sala et al., 2007; Silva et al., 2009; Hungria et al., 2010; Lana et al., 2012). The symbiosis between plant and bacteria alters plant metabolism and improves its photosynthetic activity, which allows for greater amounts of photoassimilates to be translocated to the grains (Alen'kina et al., 2014) and results in increased productivity.

In 2014, foliar inoculation and seed inoculation both plus $70 \mathrm{~kg} \mathrm{ha}^{-1}$ nitrogen increased the grain yield of the TBIO Quartzo cultivar in 31.7 and $36.8 \%$, respectively, compared with $70 \mathrm{~kg} \mathrm{ha}^{-1}$ nitrogen alone. In that same year, foliar and seed inoculation plus 140 $\mathrm{kg} \mathrm{ha}^{-1}$ nitrogen increased grain yield in 14 and $13.5 \%$, respectively. These productivity increases with $70 \mathrm{~kg}$

Table 4. Mass of a thousand grains ( $\mathrm{g}$ ) of wheat (Triticum aestivum) cultivars subjected to different forms of inoculation with Azospirillum brasilense and nitrogen doses in the 2014 and 2015 crop years ${ }^{(1)}$.

\begin{tabular}{|c|c|c|c|c|c|c|c|}
\hline \multirow[t]{2}{*}{ Crop year } & \multicolumn{4}{|c|}{ Inoculation form } & \multicolumn{3}{|c|}{ Cultivar } \\
\hline & Control & Foliar $(\mathrm{F})$ & Seed $(S)$ & $\mathrm{F}+\mathrm{S}$ & BRS Parrudo & TBIO Quartzo & TBIO Sinuelo \\
\hline 2014 & $30.0 \mathrm{~b}$ & $30.0 \mathrm{~b}$ & $30.5 b$ & $32.0 \mathrm{a}$ & $30.5 b$ & $31.5 \mathrm{a}$ & $30.5 b$ \\
\hline 2015 & - & - & - & - & $31.8 \mathrm{a}$ & $31.5 \mathrm{a}$ & $30.0 \mathrm{~b}$ \\
\hline
\end{tabular}

${ }^{(1)}$ Means followed by equal letters, within inoculation forms and cultivars, do not differ by Scott-Knott's test, at 5\% probability.

Table 5. Grain yield $\left(\mathrm{kg} \mathrm{ha}^{-1}\right)$ of wheat (Triticum aestivum) cultivars subjected to different forms of inoculation with Azospirillum brasilense and nitrogen doses in the 2014 and 2015 crop years ${ }^{(1)}$.

\begin{tabular}{|c|c|c|c|c|c|}
\hline \multirow{2}{*}{$\begin{array}{l}\text { Nitrogen dose } \\
\left(\mathrm{kg} \mathrm{ha}^{1}\right)\end{array}$} & \multirow[t]{2}{*}{ Cultivar } & \multicolumn{4}{|c|}{ Inoculation form } \\
\hline & & Control & Foliar $(\mathrm{F})$ & Seed $(\mathrm{S})$ & $\mathrm{F}+\mathrm{S}$ \\
\hline & & \multicolumn{4}{|c|}{2014 crop year } \\
\hline \multirow{3}{*}{0} & BRS Parrudo & $\beta 1,750 \mathrm{aA}$ & $\beta 1,947 \mathrm{aA}$ & $\alpha 1,181 \mathrm{aB}$ & $\alpha 1,313 b B$ \\
\hline & TBIO Sinuelo & $\beta 1,317 \mathrm{aB}$ & $\mathrm{Y} 1,224 \mathrm{bB}$ & $\beta 901 \mathrm{bC}$ & $\mathrm{Y} 1,746 \mathrm{aA}$ \\
\hline & TBIO Quartzo & $\mathrm{Y} 1,482 \mathrm{aA}$ & $\mathrm{Y} 1,506 \mathrm{bA}$ & $\mathrm{Y} 1,093 \mathrm{aB}$ & $\beta 1,167 \mathrm{bB}$ \\
\hline \multirow{3}{*}{70} & BRS Parrudo & $\alpha 2,430 \mathrm{aA}$ & $\beta 1,671 \mathrm{bB}$ & $\alpha 1,678 \mathrm{bB}$ & $\alpha 1,551 \mathrm{bB}$ \\
\hline & TBIO Sinuelo & $\beta 1,440 \mathrm{cD}$ & $\beta 2,191 \mathrm{aB}$ & $\alpha 1,859 \mathrm{bC}$ & $\beta 2,627 \mathrm{aA}$ \\
\hline & TBIO Quartzo & $\beta 1,925 \mathrm{bB}$ & $\beta 2,536 \mathrm{aA}$ & $\beta 2,633 \mathrm{aA}$ & $\beta 1,124 \mathrm{cC}$ \\
\hline \multirow{3}{*}{140} & BRS Parrudo & $\alpha 2,831 \mathrm{bA}$ & $\alpha 2,485 \mathrm{bA}$ & $\alpha 1,401 \mathrm{cB}$ & $\alpha 2,785 \mathrm{bA}$ \\
\hline & TBIO Sinuelo & $\alpha 3,382 \mathrm{aA}$ & $\alpha 2,600 \mathrm{bB}$ & $\alpha 1,961 b C$ & $\alpha 3,263 \mathrm{aA}$ \\
\hline & TBIO Quartzo & $\alpha 2,958 \mathrm{bB}$ & $\alpha 3,383 \mathrm{aA}$ & $\alpha 3,366 \mathrm{aA}$ & $\alpha 2,508 \mathrm{bC}$ \\
\hline \multirow[t]{2}{*}{ CV (\%) } & & \multicolumn{4}{|c|}{12.27} \\
\hline & & \multicolumn{4}{|c|}{2015 crop year } \\
\hline \multirow{3}{*}{0} & BRS Parrudo & Y1,930cB & $\beta 2,623 \mathrm{bA}$ & $\mathrm{Y} 1,912 \mathrm{cB}$ & $\mathrm{Y} 1,938 \mathrm{bB}$ \\
\hline & TBIO Sinuelo & $\mathrm{Y} 2,494 \mathrm{bB}$ & $\alpha 3,198 \mathrm{aA}$ & $\mathrm{Y} 2,196 \mathrm{bC}$ & $\beta 2,537 \mathrm{aB}$ \\
\hline & TBIO Quartzo & $\alpha 3,305 \mathrm{aA}$ & $\mathrm{Y} 1,803 \mathrm{cD}$ & $\beta 2,945 \mathrm{aB}$ & $\mathrm{Y} 2,060 \mathrm{bC}$ \\
\hline \multirow{3}{*}{70} & BRS Parrudo & $\beta 2,875 \mathrm{aB}$ & $\alpha 3,148 \mathrm{aA}$ & $\beta 2,410 \mathrm{bC}$ & $\beta 2,461 \mathrm{bC}$ \\
\hline & TBIO Sinuelo & $\beta 2,872 \mathrm{aB}$ & $\alpha 3,242 \mathrm{aA}$ & $\beta 2,534 \mathrm{bC}$ & $\alpha 2,911 \mathrm{aB}$ \\
\hline & TBIO Quartzo & $\beta 3,068 \mathrm{aA}$ & $\beta 2,921 \mathrm{bA}$ & $\beta 2,877 \mathrm{aA}$ & $\beta 2,372 \mathrm{bB}$ \\
\hline \multirow{3}{*}{140} & BRS Parrudo & $\alpha 3,378 \mathrm{aA}$ & $\alpha 2,992 b B$ & $\alpha 2,944 \mathrm{bB}$ & $\alpha 3,130 \mathrm{aB}$ \\
\hline & TBIO Sinuelo & $\alpha 3,189 \mathrm{aA}$ & $\alpha 3,313 \mathrm{aA}$ & $\alpha 2,751 \mathrm{bB}$ & $\alpha 2,836 \mathrm{bB}$ \\
\hline & TBIO Quartzo & $\alpha 3,374 \mathrm{aA}$ & $\alpha 3,285 \mathrm{aA}$ & $\alpha 3,227 \mathrm{aA}$ & $\alpha 2,979 \mathrm{bB}$ \\
\hline CV (\%) & & \multicolumn{4}{|c|}{4.42} \\
\hline
\end{tabular}


$\mathrm{N}$, promoted by the bacteria, are due to the growth and increase of the root system, causing the roots to explore larger soil volume, increasing nutrient and water absorption (Bashan \& de-Bashan, 2010). With $140 \mathrm{~kg}$ it is possible to consider that the higher amount of nitrogen fertilizer affected the inoculation effect. According to Hartmann (1988), the efficiency of biological fixation in Azospirillum spp. It is rapidly reduced or even inhibited in the presence of higher $\mathrm{N}$ concentrations in the soil, especially ammonium, which inhibits the activity of nitrogenase in bacteria, responsible for the conversion of nitrogen from the atmosphere $\left(\mathrm{N}_{2}\right)$ to a plant assimilable form. The results reinforce the fact that inoculation with Azospirillum brasilense should always be associated with nitrogen fertilization favoring additional contributions to wheat yield (Piccinin et al., 2013).

In 2015, inoculation did not favor plant yield for the TBIO Quartzo cultivar. Possibly, the bacterium had competitors in the soil microbial community, since $A$. brasilense is predominantly a rhizospheric bacterium (Dobbelaere et al., 2003).

\section{Conclusion}

Seed inoculation with the bacterium Azospirillum brasilense, whether alone or associated with foliar inoculation, consistently increases grain yield and other productivity components of wheat (Triticum aestivum).

\section{Acknowledgments}

To Coordenação de Aperfeiçoamento de Pessoal de Nível Superior (Capes), for scholarship; and to Conselho Nacional de Desenvolvimento Científico e Tecnológico (CNPq), for financial support.

\section{References}

ALEN'KINA, S.A.; BOGATYREV, V.A.; MATORA, L.Y.; SOKOLOVA, M.K.; CHERNYSHOVA, M.P.; TRUTNEVA, K.A.; NIKITINA, V.E. Signal effects of the lectin from the associative nitrogen-fixing bacterium Azospirillum brasilense $\mathrm{Sp} 7$ in bacterial-plant root interactions. Plant and Soil, v.381, p.337-349, 2014. DOI: https://doi.org/10.1007/s11104-014-2125-6.

BASHAN, Y.; DE-BASHAN, L.E. How the plant growthpromoting bacterium Azospirillum promotes plant growth - a critical assessment. In: SPARKS, D.L. (Ed.). Advances in Agronomy. London: Elsevier, 2010. v.108, p.77-136. DOI: https://doi.org/10.1016/S0065-2113(10)08002-8.
BERGAMASCHI, C.; ROESCH, L.F.W.; QUADROS, P.D. de; CAMARGO, F.A. de O. Ocorrência de bactérias diazotróficas associadas a cultivares de sorgo forrageiro. Ciência Rural, v.37, p.727-733, 2007. DOI: https://doi.org/10.1590/S010384782007000300019 .

CARVAlHO, P. de T.; BELEIA, A. D.P. Alterações físicoquímicas e atividade enzimática de trigo com germinação précolheita. Revista Ciência Agronômica, v.46, p.524-531, 2015. DOI: https://doi.org/10.5935/1806-6690.20150034.

CORNACINI, J.H.O.; ALVES, C.Z. Doses de nitrogênio em cobertura associado à inoculação de Azospirillum brasilense via foliar na cultura do sorgo. Journal of Agronomic Sciences, v.3, p.216-229, 2014.

DOBBELAERE, S.; VANDERLEYDEN, J.; OKON, Y. Plant growth-promoting effects of diazotrophs in the rhizosphere. Critical Reviews in Plant Sciences, v.22, p.107-149, 2003. DOI: https://oi.org/10.1080/713610853.

FERREIRA, D.F. Sisvar: a computer statistical analysis system. Ciência e Agrotecnologia, v.35, p.1039-1042, 2011. DOI: https://doi.org/10.1590/S1413-70542011000600001.

FRANCESCHI, L. de; BENIN, G.; GUARIENTI, E.; MARCHIORO, V.S.; MARTIN, T.N. Fatores pré-colheita que afetam a qualidade tecnológica de trigo. Ciência Rural, v.39, p.1624-1631, 2009. DOI: https://doi.org/10.1590/S010384782009005000060 .

GALINDO, F.S.; TEIXEIRA FILHO, M.C.M.; BUZETTI, S.; SANTINI, J.M.K.; ALVES, C.J.; LUDKIEWICZ, M.G.Z. Wheat yield in the Cerrado as affected by nitrogen fertilization and inoculation with Azospirillum brasilense. Pesquisa Agropecuária Brasileira, v.52, p.794-805, 2017. DOI: https://doi.org/10.1590/s0100-204x2017000900012.

HARTMANN, A. Ecophysiological aspects of growth and nitrogen fixation in Azospirillum spp. Plant and Soil, v.110, p. 225-238, 1988. DOI: https://doi.org/10.1007/BF02226803.

HELDWEIN, A.B.; BURIOL, G.A.; STRECK, N.A. O clima de Santa Maria. Revista Ciência \& Ambiente, v.38, p.43-58, 2009.

HUNGRIA, M.; CAMPO, R.J.; SOUZA, E.M.; PEDROSA, F.O. Inoculation with selected strains of Azospirillum brasilense and A. lipoferum improves yields of maize and wheat in Brazil. Plant and Soil, v.331, p.413-425, 2010. DOI: https://doi.org/10.1007/ s11104-009-0262-0.

LANA, M. do C.; DARTORA, J.; MARINI, D.; HANN, J.E. Inoculation with Azospirillum, associated with nitrogen fertilization in maize. Revista Ceres, v.59, p.399-405, 2012. DOI: https://doi.org/10.1590/S0034-737X2012000300016.

MEHNAZ, S.; KOWALIK, T.; REYNOLDS, B.; LAZAROVITS, G. Growth promoting effects of corn (Zea mays) bacterial isolates under greenhouse and field conditions. Soil Biology \& Biochemistry, v.42, p.1848-1856, 2010. DOI: https://doi.org/10.1016/j.soilbio.2010.07.003.

MONTEIRO, F.P.; PACHECO, L.P.; LORENZETTI, E.R.; ARMESTO, C.; SOUZA, P.E. de; ABREU, M.S. de. Exsudatos radiculares de plantas de cobertura no desenvolvimento de Sclerotinia sclerotiorum. Bioscience Journal, v.28, p.87-93, 2012. 
PICCININ, G.G.; BRACCINI, A.L.; DAN, L.G.M.; SCAPIM, C.A.; RICCI, T.T.; BAZO, G.L. Efficiency of seed inoculation with Azospirillum brasilense on agronomic characteristics and yield of wheat. Industrial Crops and Products, v.43, p.393-397, 2013. DOI: https://doi.org/10.1016/j.indcrop.2012.07.052.

REUNIÃO DA COMISSÃO BRASILEIRA DE PESQUISA DE TRIGO E TRITICALE, 10., 2016, Londrina. Informações técnicas para trigo e triticale - safra 2017. Brasília: Embrapa, 2017. 240p. Editado por Sergio Ricardo Silva, Manoel Carlos Bassoi, José Salvador Simoneti Foloni.

SALA, V.M.R.; CARDOSO, E.J.B.N.; FREITAS, J.G. de; SILVEIRA, A.P.D. da. Resposta de genótipos de trigo à inoculação de bactérias diazotróficas em condições de campo. Pesquisa Agropecuária Brasileira, v.42, p.833-842, 2007. DOI: https://doi.org/10.1590/S0100-204X2007000600010.

SANGOI, L.; BERNS, A.C.; ALMEIDA, M.L. de; ZANIN, C.G.; SCHWEITZER, C. Características agronômicas de cultivares de trigo em resposta à época da adubação nitrogenada de cobertura. Ciência Rural, v.37, p.1564-1570, 2007. DOI: https://doi.org/10.1590/S0103-84782007000600010.
SANTOS, H.G. dos; JACOMINE, P.K.T.; ANJOS, L.H.C. dos; OLIVEIRA, V.Á. de; LUMBRERAS, J.F.; COELHO, M.R.; ALMEIDA, J.A. de; CUNHA, T.J.F.; OLIVEIRA, J.B. de. Sistema brasileiro de classificação de solos. 3.ed. rev. e ampl. Brasília: Embrapa, 2013. 353p.

SILVA, M.F. da; OLIVEIRA, P.J. de; XAVIER, G.R.; RUMJANEK, N.G.; REIS, V.M. Inoculantes formulados com polímeros e bactérias endofíticas para a cultura da cana-deaçúcar. Pesquisa Agropecuária Brasileira, v.44, p.1437-1443, 2009. DOI: https://doi.org/10.1590/S0100-204X2009001100010.

TEIXEIRA FILHO, M.C.M.; TARSITANO, M.A.A.; BUZETTI, S.; BERTOLIN, D.C.; COLOMBO, A. de S.; NASCIMENTO, V. do. Análise econômica da adubação nitrogenada em trigo irrigado sob plantio direto no cerrado. Revista Ceres, v.57, p.446-443, 2010. DOI: https://doi.org/10.1590/S0034-737X2010000400002.

WIETHÖLTER, S. Fertilidade do solo e a cultura do trigo no Brasil. In: PIRES, J.L.F.; VARGAS, L.; CUNHA, G.R. da (Ed.). Trigo no Brasil: bases para produção competitiva e sustentável. Passo Fundo: Embrapa Trigo, 2011. Cap. 6, p.135-184. 